I N S T I T U T O

$\mathrm{DE}$

M E D I C I N A

T R O P I C A L

$\mathrm{DE}$

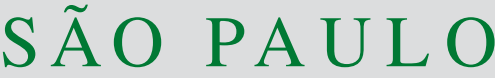

JOURNAL OF THE SÃO PAULO INSTITUTE OF TROPICAL MEDICINE

${ }^{1}$ Universidade de São Paulo, Faculdade de Medicina, Hospital das Clínicas, LIM-06 Imunopatologia da Esquistossomose, São Paulo, São Paulo, Brazil

Universidade de São Paulo, Faculdade de Medicina, Hospital das Clínicas, São Paulo, São Paulo, Brazil

${ }^{3}$ Universidade de São Paulo, Faculdade de Medicina, Instituto de Medicina Tropical de São Paulo, São Paulo, São Paulo, Brazil

Correspondence to: Susana Angélica

Zevallos Lescano

Universidade de São Paulo, Faculdade de Medicina, Hospital das Clínicas, LIM-06 Imunopatologia da Esquistossomose, Av. Dr. Eneas Carvalho de Aguiar, 470, CEP 05403-000, São Paulo, SP, Brazil

Tel: +551130617063

E-mail: suzeles@usp.br

Received: 4 November 2021

Accepted: 6 January 2022

\section{Toxocara canis 30-35 kDa excretory-secretory antigen is an important marker in mice challenged by inocula containing different parasite load levels}

\author{
Gabriela Rodrigues e Fonseca ${ }^{\circledR}$, Marcelo Andreetta Corral ${ }^{\circledR 1}$, Fabiana \\ Martins de Paula 1,2,3, Dirce Mary Correia Lima Meisel' ${ }^{1}$, Ronaldo Cesar \\ Borges Gryschek ${ }^{\circledR 1,2,3}$, Susana Angélica Zevallos Lescano ${ }^{\circledR 1,3}$
}

\section{ABSTRACT}

The Western-blotting technique was applied to identify antigenic fractions of excretorysecretory Toxocara canis antigen recognized by IgG antibodies throughout an experimental infection in mice challenged by different inocula. Mice were inoculated with 5, 50 and 500 embryonated eggs and serum samples were collected 15, 30, 60, 90 and 120 days post-infection. Serum samples were analyzed using an excretory-secretory Toxocara antigen. Antibodies recognized antigenic fractions from 30 to $90 \mathrm{kDa}$. The protein fraction of $30-35 \mathrm{kDa}$ was the most frequently recognized regardless of the size of inoculum and the stage of infection represented by the different collection times, but the antigenic recognition was more evident in groups infected with 50 and 500 eggs. This study presents an antigenic panel of the excretory-secretory antigen of $T$. canis and suggests that the $30-35 \mathrm{kDa}$ antigenic fraction is a promising marker of the infection and should be further explored in future studies on experimental toxocariasis.

KEYWORDS: BALB/c mice. Toxocara canis. Toxocariasis. Western blotting. Immunodiagnosis. Antigenic fractions.

\section{INTRODUCTION}

Toxocariasis, a zoonosis caused by Toxocara canis and Toxocara cati nematode larvae, causes a variety of syndromes, including visceral larva migrans, ocular larva migrans, common or covert toxocariasis and neurotoxocariasis ${ }^{1-4}$. Rats and mice are paratenic hosts, widely used in research due to the similarities of their infections with those of humans with respect to the host-parasite relationship, larvae migration patterns, in addition to being easily maintained in the laboratory ${ }^{5-8}$.

In the absence of direct evidence of the parasite infection in paratenic hosts, indirect detection, especially of antibodies using immunological methods has a relevant role in the diagnosis of toxocariasis ${ }^{9}$. The literature has highlighted the use of Westernblotting (WB) techniques for the investigation of many immunological aspects ${ }^{1,2,8-12}$. The recognition of antigenic fractions of the parasite by $\operatorname{IgG}$ antibodies throughout experimental infections induced by different inocula has not yet been evaluated. This study aimed to describe an antigen recognition panel by IgG anti-Toxocara antibodies in mice infected with different $T$. canis inocula throughout the infection.

\section{MATERIALS AND METHODS}

Twenty-five BALB/c specific pathogen-free male mice, 6-8 weeks old, 
acquired from Centro de Bioterismo of the Faculdade de Medicina of the Universidade de Sao Paulo, were divided into three groups (I, II and III). Six animals in each group were infected via intragastric intubation with 5, 50 or 500 embryonated T. canis eggs (L3), suspended in $200 \mu \mathrm{L}$ of saline solution, respectively. Seven non-infected mice received $200 \mu \mathrm{L}$ of saline solution (negative controls). All the animals received water and diet ad libitum and were treated in accordance with the ethical guidelines of the Animal Ethics Committee of the Instituto de Medicina Tropical de Sao Paulo (protocol CPE-IMT/254) and Ethics Committee on Animal Studies of the Faculdade de Medicina of the Universidade de Sao Paulo (protocol $162 / 15)$. Animals in all groups were anesthetized with xylazine and ketamine at concentrations of $10 \mathrm{mg} / \mathrm{kg}$ and $100 \mathrm{mg} / \mathrm{kg}$, respectively, and serum samples were obtained 15, 30, 60, 90 and 120 days post-infection (dpi) by the retro orbital plexus, divided into aliquots and stored at $-20^{\circ} \mathrm{C}$. Animals were euthanized by intravenous administration of a thiopental overdose of $100 \mathrm{mg} / \mathrm{kg}$. Confirmation on the loss of consciousness and death were made by cervical dislocation at the end of the experiment.

T. canis excretory-secretory antigen (TES-Ag) was prepared following the procedure described by Savigny ${ }^{13}$ with modifications made by Elefant et al. ${ }^{14}$. Briefly, T. canis eggs were collected from the uterus of adult females, embryonated in $2 \%$ formalin at room temperature and observed weekly for embryonation. When embryonated, eggs were collected in a conic tube and centrifuged at $170 \mathrm{Xg}$ for $5 \mathrm{~min}$ with saline solution until the formalin was completely removed. Then, the precipitate was resuspended in 5\% sodium hypochlorite for $5 \mathrm{~min}$ for the removal of the proteic outer layer. Next, the eggs were centrifuged with saline solution as described before. Then, they were transferred into an Erlenmeyer containing glass pearls and RPMI medium (RPMI 1649 Sigma Aldrich, a subsidiary of Merck Inc., Burlington, MA, USA) with $80 \mu \mathrm{g} / \mathrm{mL}$ of gentamicin. This content was gently shaken for up to $30 \mathrm{~min}$ to release larvae, and then transferred into a modified Baermann apparatus for $2 \mathrm{~h}$. The medium was transferred into $5 \mathrm{~mL}$ tubes and incubated at $37^{\circ} \mathrm{C}$, and was afterwards removed and replaced with fresh medium at weekly intervals. A protease inhibitor $(5 \mathrm{~mL} / \mathrm{mL}$ of $200 \mathrm{mM}$ phenyl- methyl-sulfonyl-fluoride) was added to the supernatant removed from the medium. Later, the antigen in the supernatant was concentrated with the aid of an Amiconfilter (Millipore Inc., a subsidiary of Merck Inc., Burlington, MA, USA), and its protein concentration was determined by the Lowry assay ${ }^{15}$.

One hundred and forty micrograms of the TES antigenic fraction $(88 \mu \mathrm{g} / \mu \mathrm{L})$ were subjected to polyacrylamide gel electrophoresis (SDS-PAGE), using a $12 \%$ gel. The samples were suspended in buffer [0.5 M Tris- $\mathrm{HCl}(\mathrm{pH} 6.8)$, $10 \%$ sodium dodecylsulfate (SDS), $20 \%$ glycerol, $0.1 \mathrm{M}$ dithiothreitol, $0.2 \%$ bromophenol blue] and heated at $100{ }^{\circ} \mathrm{C}$ for $5 \mathrm{~min}$. After the addition of buffer $(0.3 \%$ Tris, $1.5 \%$ glycine), electrophoresis was performed at $40 \mathrm{~mA}$ and $100 \mathrm{~V}$ together with a molecular weight standard (10-260 kDa; Thermo Fischer Scientific, Waltham, USA). Then, the proteins on the gel were transferred to polyvinylidene fluoride (PVDF) membranes $(0.2 \mu \mathrm{m})$ (Bio-Rad Laboratories, Hercules, CA, USA) in a Mini Trans-Blot system with buffer (10 mM Tris-glycine, 95 $\mathrm{mM} 20 \%$ ethanol, $10 \% \mathrm{SDS}$ ) at $200 \mathrm{~mA}$ and $50 \mathrm{~V}$. The membranes were cut into strips of approximately $3 \mathrm{~mm}$ and stored until use ${ }^{16}$.

The WB technique was carried out as described previously ${ }^{14,16}$. Membranes were blocked for $1 \mathrm{~h}$ at room temperature with phosphate-saline buffer (PBS, $\mathrm{pH}$ 7.2), Tween 20, and 5\% skimmed milk powder (PBSTSM) under constant agitation. The membranes were washed three times with PBS-Tween solution (PBS-T). Serum samples from each animal of all groups were diluted 1: 50 in 1\% PBSTSM and added to the membranes, followed by an incubation at $4{ }^{\circ} \mathrm{C}$ for $18 \mathrm{~h}$ under constant agitation. The membranes were washed six times for 5 min each with PBS-T, and incubated for two $h$ with anti-mouse IgG conjugated with horseradish peroxidase ( $\gamma$-chain specific; Sigma-Aldrich, USA) diluted 1: 200 in 1\% PBSTSM. Binding was detected using DAB substrate (Sigma-Aldrich, USA) in the dark until bands appeared. The antigenic components were analyzed by the VisionWorks LS Analysis software (Analytik Jena GmbH, Germany). Data were expressed as absence or presence of recognizable bands.

\section{RESULTS}

Immunogenic fractions were recognized by IgG antiToxocara antibodies in serum samples of the three groups of infected mice throughout the experiment (Figure 1). Serum samples from negative control animals did not show any recognition of TES-Ag proteins. Serum antibodies sequentially recognized different TES components. While group I mice began to show reactivity $30 \mathrm{dpi}$, groups II and III animals showed recognition at the beginning of the infection $(15 \mathrm{dpi})$. It was observed that the reactivity of antibodies was strongly increased by the end of the infection (120 dpi).

Immunogenic fractions of TES-Ag were detected at 6065, 40-45 and 30-35 kDa, in group I. In groups II and III, antigenic fractions of 90-95, 80-85, 70-75, 60-65, 50-55, 40-45 and 30-35 kDa were recognized. The 30-35 kDa 


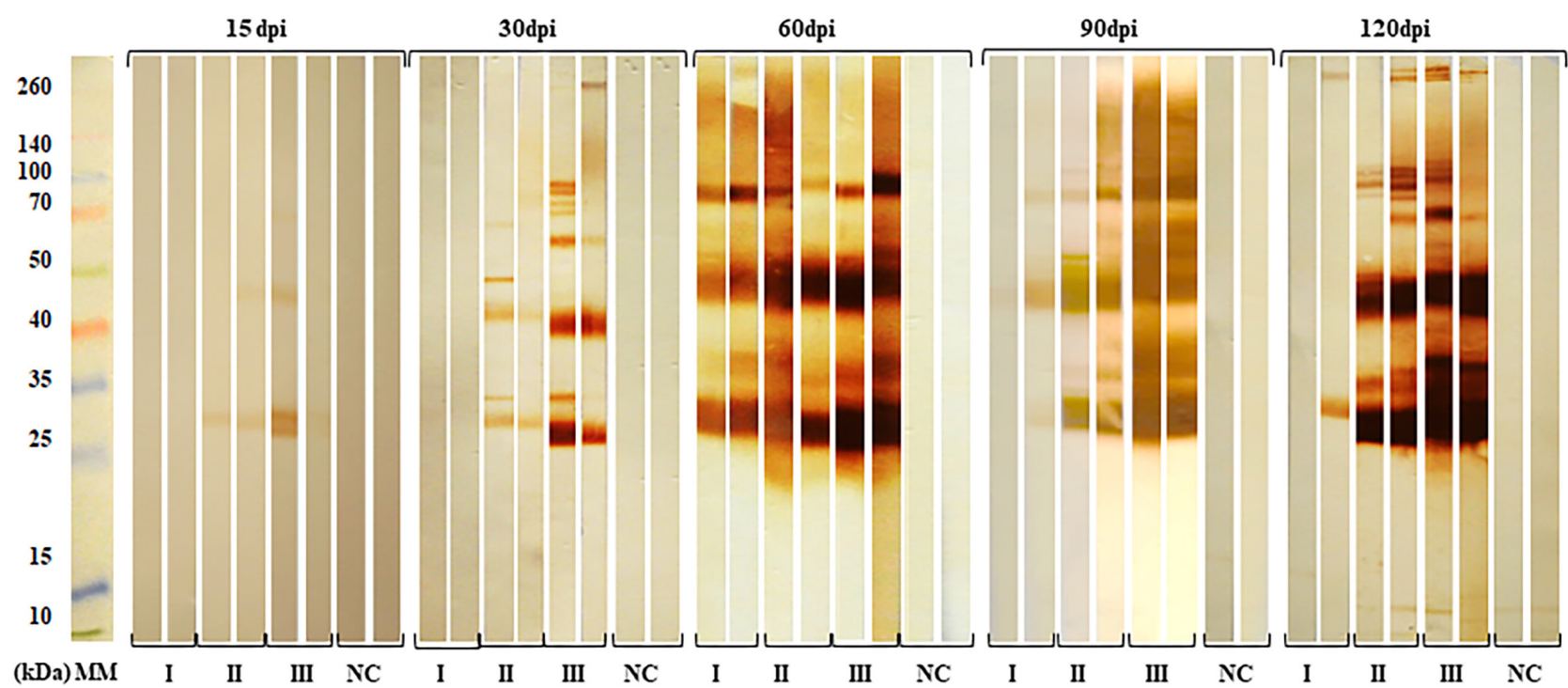

Figure 1 - Dynamics of the recognition of protein fractions by anti-Toxocara IgG antibodies in serum samples of mice from groups I, II and III, at collection times corresponding to 15, 30, 60, 90 and $120 \mathrm{dpi}$. MW = molecular weight marker; NC = negative controls.

Table 1 - Frequency of antigenic fractions recognized by IgG anti-Toxocara antibodies from animals of groups I, II and III, according to the days post-infection (dpi). Numbers represent percentages of detection.

\begin{tabular}{|c|c|c|c|c|c|c|c|c|c|c|c|c|c|c|c|}
\hline \multirow{2}{*}{$\mathrm{kDa}$} & \multicolumn{3}{|c|}{$15 \mathrm{dpi}$} & \multicolumn{3}{|c|}{$30 \mathrm{dpi}$} & \multicolumn{3}{|c|}{$60 \mathrm{dpi}$} & \multicolumn{3}{|c|}{$90 \mathrm{dpi}$} & \multicolumn{3}{|c|}{$120 \mathrm{dpi}$} \\
\hline & $\mathrm{I}$ & II & III & 1 & II & III & 1 & II & III & 1 & II & III & 1 & II & III \\
\hline $90-95$ & 0 & 0 & 0 & 0 & 0 & 16.7 & 0 & 16.7 & 0 & 0 & 0 & 0 & 0 & 0 & 0 \\
\hline $80-85$ & 0 & 0 & 0 & 0 & 0 & 16.7 & 0 & 33.3 & 0 & 0 & 66.7 & 33.3 & 0 & 100 & 83.3 \\
\hline $70-75$ & 0 & 0 & 0 & 0 & 0 & 16.7 & 0 & 33.3 & 0 & 0 & 66.7 & 33.3 & 0 & 100 & 83.3 \\
\hline $60-65$ & 0 & 0 & 0 & 0 & 0 & 0 & 83.3 & 100 & 83.3 & 33.3 & 66.7 & 100 & 0 & 83.3 & 100 \\
\hline $50-55$ & 0 & 0 & 0 & 0 & 33.3 & 100 & 0 & 0 & 33.3 & 0 & 0 & 0 & 0 & 66.7 & 66.7 \\
\hline $40-45$ & 0 & 33.3 & 33.3 & 16.7 & 100 & 66.7 & 83.3 & 100 & 100 & 66.7 & 100 & 100 & 0 & 100 & 100 \\
\hline 30-35 & 0 & 66.7 & 66.7 & 16.7 & 100 & 100 & 100 & 100 & 100 & 66.7 & 100 & 100 & 33.3 & 100 & 100 \\
\hline
\end{tabular}

bands was the most frequently recognized antigenic fraction amongst infected animals, followed by the $40-45 \mathrm{kDa}$ fraction (Table 1).

\section{DISCUSSION}

Few studies have been performed using WB in experimental toxocariasis ${ }^{11,17,18}$, but none of them assessed the recognition pattern of antigenic fractions related to the inoculum size. The present study observed sequential antigen recognition throughout the experimental infection in all groups. This fact might be related to antigenic components secreted by $T$. canis larvae during their migration to various tissues, or even to metabolites released during larval elimination ${ }^{17}$. Recognition of a greater number of antigenic fractions by $\mathrm{IgG}$ antibodies from mice infected with 1,000 T. canis larvae from 30 dpi onwards has been demonstrated ${ }^{18}$, and it was also observed in this study. Therefore, this study suggests that the number of TES-Ag fractions recognized by $\operatorname{IgG}$ antibodies can estimate whether an infection is in its initial or advanced stage ${ }^{17}$.

The panel of immunogenic fractions identified in the present study showed distinct and variable recognition. The number of antigenic fractions recognized in all groups was directly related to the parasite load (inoculum size). This fact might explain the recognition of smaller numbers or less intense antigenic fractions in group I. The immune response of mice infected with $T$. canis has been related to the inoculum ${ }^{6,19}$. We can infer that the remaining larvae from group I might not have stimulated the immune response as observed in animals from groups II and III that were challenged by higher parasite load levels.

Throughout the experimental infection, an increase in the number of protein fractions recognized by $\operatorname{IgG}$ in the animals was observed. Similar results were revealed in experimental infections of gerbils, rabbits and other mice $^{11,17,18}$. However, it is important to emphasize that all these studies evaluated only inoculum sizes containing 
higher doses $(\geq 1,000) T$. canis larvae or eggs.

Interestingly, the 30-35 kDa fractions were recognized by groups II and III at the initial phase of the infection. Other authors observed protein fractions of $32 \mathrm{kDa} 20 \mathrm{dpi}$ in gerbils and of $35 \mathrm{kDa} 14 \mathrm{dpi}$ in rabbits inoculated with 1,000 and 5,000 T. canis eggs, respectively ${ }^{11,17}$. In contrast, in group I, this fraction was only recognized after $30 \mathrm{dpi}$. These results may indicate that this protein fraction is not immunogenic enough at the initial phase of the infection, especially in the presence of low inocula sizes. In addition, Nguyen et al. ${ }^{18}$ demonstrated that $33.1 \mathrm{kDa}$ E/S protein of $T$. canis was the most reactive fraction recognized by specific IgG in animals and humans. Unlike the present study, serum samples from rabbits were evaluated only after $30 \mathrm{dpi}$. In previous studies, this fraction has been applied to the diagnosis of human toxocariasis,

\section{CONCLUSION}

As far as we know, this is the first study that describes an antigenic recognition panel by antibodies present in serum of animals inoculated with small size inocula (low parasite load) as well as intermediate and high parasite load inocula, at different times post infection ${ }^{23}$. In addition, the recognition of the 30-35 $\mathrm{kDa}$ fraction in experimental animals infected with low parasite load (5 eggs) can mimic the course of infection in occult human toxocariasis ${ }^{19}$.

The migration pattern of Toxocara larvae in mice starts with the visceral stage andsubsequently evolves to the myotropic-neurotropic stage, corresponding to the collection times $10 \mathrm{dpi}$ and after $10 \mathrm{dpi}$, respectively ${ }^{5}$. A possible re-migration to the tissues via the bloodstream may occur $^{19,24,25}$. Therefore, the increase and decrease of protein fractions might be related to the larval migration pattern at that time or the elimination of parasites by the immune system, or the momentary parasite load. Thus, our TES-Ag antigenic panel highlights the $30-35 \mathrm{kDa}$ fraction as an important marker of murine infection caused by T. canis, especially in the advanced stages of infection, even in the occurrence of infection with very low larval load. These results support further research for the improvement of WB for diagnosis of murine and human toxocariasis.

\section{AUTHORS' CONTRIBUTIONS}

GRF and MAC: investigation, validation, writing, visualization; DMCLM: investigation; FMP: conceptualization, methodology, writing, supervision; RCBG: writing, review, editing, resources; SAZL: conceptualization, methodology, resources, writing, supervision, project administration, funding acquisition.

\section{FUNDING}

This work was supported by FAPESP (grant $\mathrm{N}^{\mathrm{o}}$ 2014/07345-6) and GRF received a scholarship from CAPES (finance code 001).

\section{REFERENCES}

1. Chieffi PP, Zevallos Lescano SA, Fonseca GR, Santos SV. Human toxocariasis: 2010 to 2020 contributions from Brazilian researchers, Res Rep Trop Med. 2021;12:81-91.

2. Fillaux J, Magnaval JF. Laboratory diagnosis of human toxocariasis. Vet Parasitol. 2013;193:327-36.

3. Macpherson CN. The epidemiology and public health importance of toxocariasis: a zoonosis of global importance. Int J Parasitol. 2013;43:999-1008.

4. Overgaauw PA, van Knapen F. Veterinary and public health aspects of Toxocara spp. Vet Parasitol. 2013;193:398-403.

5. Abo-Shehada MN, Herbert IV. The migration of larval Toxocara canis in mice II. Post-intestinal migration in primary infections. Vet Parasitol. 1984;17:75-83.

6. Pinelli E, Brandes S, Dormans J, Fonville M, Hamilton CM, der Giessen J. Toxocara canis: effect of inoculum size on pulmonary pathology and cytokine expression in BALB/c mice. Exp Parasitol. 2007;115:76-82.

7. Fan CK, Holland CV, Loxton K, Barghouth U. Cerebral toxocariasis: silent progression to neurodegenerative disorders? Clin Microbiol Rev. 2015;28:663-86.

8. Poulsen CS, Skov S, Yoshida A, Skallerup P, Maruyama H, Thamsborg SM, et al. Differential serodiagnostics of Toxocara canis and Toxocara cati: is it possible? Parasite Immunol. 2015;37:204-7

9. Rubinsky-Elefant G, Hoshino-Shimizu S, Jacob CM, Sanchez MC, Ferreira AW. Potential immunological markers for diagnosis and therapeutic assessment of toxocariasis. Rev Inst Med Trop Sao Paulo. 2011;53:61-5.

10. Sarimehmetoğlu HO, Burgu A, Aycicek H, Gönenç B, Tanyuksel M, Kara M. Application of western blotting procedure for the immunodiagnosis of visceral larva migrans in mice by using excretory/secretory antigens. Dtsch Tierarztl Wochenschr. 2001;108:390-2.

11. Morales OL, Lopez MC, Nicholls RS, Agudelo C. Identification of Toxocara canis antigens by western blot in experimentally infected rabbits. Rev Inst Med Trop Sao Paulo. 2002;44:213-6.

12. Sommerfelt IE, Santillán G, Mira G, Ribicich M, Betti A, De Torres R. Toxocara canis infections in a pig model: immunological, haematological and blood biochemistry responses. J Helminthol. 2006;80:73-7.

13. Savigny DH. In vitro maintenance of Toxocara canis larvae and a simple method for the production of Toxocara ES antigen 
for use in serodiagnostic tests for visceral larva migrans. J Parasitol. 1975;61:781-2.

14. Elefant GR, Shimizu SH, Sanchez MC, Jacob CM, Ferreira AW. A serological follow-up of toxocariasis patients after chemotherapy based on the detection of $\operatorname{IgG}, \operatorname{IgA}$, and $\operatorname{IgE}$ antibodies by enzyme-linked immunosorbent assay. J Clin Lab Anal. 2006;20:164-72.

15. Lowry OH, Rosebrough NJ, Farr AL, Randall RJ. Protein measurement with the folin phenol reagent. J Biol Chem. 1951;193:265-75.

16. Corral MA, Paula FM, Meisel DM, Castilho VL, Gonçalves EM, Levy D, et al. Potential immunological markers for diagnosis of human strongyloidiasis using heterologous antigens. Parasitology. 2017;144:124-30.

17. Alba-Hurtado F, Muñoz-Guzmán MA, Valdivia-Anda G, Tórtora JL, Ortega-Pierres MG. Toxocara canis: larval migration dynamics, detection of antibody reactivity to larval excretorysecretory antigens and clinical findings during experimental infection of gerbils (Meriones unguiculatus). Exp Parasitol. 2009;122:1-5.

18. Nguyen HH, Vo DT, Thai TT, Le TT, Le TD, Hoang NS. The $33.1 \mathrm{kDa}$ excretory/secretory protein produced by Toxocara canis larvae serves as a potential common biomarker for serodiagnosis of toxocariasis in paratenic animals and human. Iran J Parasitol. 2017;12:69-82.
19. Fonseca GR, Santos SV, Chieffi PP, Paula FM, Gryschek RC, Zevallos Lescano SA. Experimental toxocariasis in BALB/c mice: Relationship between parasite inoculum and the IgG immune response. Mem Inst Oswaldo Cruz. 2017;112:382-6.

20. Magnaval JF, Fabre R, Maurières P, Charlet JP, Larrard B. Application of the Western blotting procedure for the immunodiagnosis of human toxocariasis. Parasitol Res. 1991;77:697-702.

21. Loukas A, Mullin NP, Tetteh KK, Moens L, Maizels RM. A novel $\mathrm{C}$-type lectin secreted by a tissue-dwelling parasitic nematode. Curr Biol. 1999;9:825-8.

22. Roldán WH, Elefant GR, Ferreira AW. Deglycosylation of Toxocara excretory-secretory antigens improves the specificity of the serodiagnosis for human toxocariasis. Parasite Immunol. 2015;37:557-67.

23. Cox DM, Holland CV. Influence of mouse strain, infective dose and larval burden in the brain on activity in Toxocara-infected mice. J Helminthol. 2001;75:23-32.

24. Cardillo N, Rosa A, Ribicich M, López C, Sommerfelt I. Experimental infection with Toxocara cati in BALB/c mice, migratory behaviour and pathological changes. Zoonoses Public Health. 2009;56:198-205.

25. Othman AA, El-Shourbagy SH, Soliman RH. Kinetics of Foxp3expressing regulatory cells in experimental Toxocara canis infection. Exp Parasitol. 2011;127:454-9. 